\title{
THE USE OF COMPOSIT MATERIALS ALTERNATIVE FIBERGLASS (COCO FIBERS \& RAGS) ON FIBERGLASS SHIP IN TRADITIONAL SHIPYARDS BENGKALIS REGENCY
}

\author{
Romadhoni1 ${ }^{1)}$ Pardi ${ }^{1)}$, Polaris, $\mathbf{N}$ \\ ${ }^{1)}$ Lecturer in Naval Architecture Studies Program Polytechnic Bengkalis \\ E-mail : onie_bks@yahoo.co.id, pardika_001@yahoo.com, polaris_2000@yahoo.com
}

\begin{abstract}
The limitations of the current wood raw material nowadays is a threat to the traditional shipbuilding business. Besides the material is expensive, it is also about the difficulty in bringing the major raw materials, fiberglass, suchas wood fiber MAT and WR (Woven Roofing). There is plan issues to ban on the use of the fiber within a certain period that accelerate the research in making the solution to be environment- free fiber.

By doing the mechanical testing of coco fibre and rags, then gained streghth the bending and optimal impact and eligible BKI standard and ASTM D- 790 and ASTM D 638 and also the use of fiberglass reinforcement material fiber alternative is expected to save expenses in making that fiberglass. To reduce the environmental waste product that do not decompose in maintaining our health (avoiding toxic substances) against syntetic fiber.

The result of bending test of composit and coir fabric is getting by using Bending Elasticity Modulus with average rags of hijab 12,88 Mpa, coco fibre 2,69 Mpa and fiber fabric undershirt 6, 57 Mpa, whereas for testing the impact obtained average value of rags hijab $0,0808 \mathrm{~kg} / \mathrm{mm}^{2}$ coco fibiers$0,16533 \mathrm{~kg} / \mathrm{mm}^{2}$ and fiber fabric undershit $0,00427 \mathrm{~kg} / \mathrm{mm}^{2}$
\end{abstract}

Key Words : fiber, Coco fibiers, Rags, streghth of Bending and Impact

\section{LATAR BELAKANG 1.1 Pendahuluan}

Banyak ditemukan galangan kapal kayu tradisional, seperti Bengkalis, Bantan, Rupat, Rupat Utara serta daerah lain yang terancam tutup dan gulung tikar bukan karena berkurangnya pesanan kapal tetapi lebih dikarenakan kesulitan dalam perolehan kayu sebagai bahan utama kapal dengan syarat, ketentuan dan kebiasaan pada jenis kayu yang digunakan untuk membuat kapal. Kondisi galangan kapal tradisional di Kabupaten Bengkalis dalam keadaan hidup segan mati tak mau alias mati suri. Hal itu terjadi karena bahan kayu yang semakin sulit dalam mendapatkannya, teknologi dan pengelolaannya tidak berkembang, daya saing rendah, serta pelanggan berubah menggunakan bahan dan teknologi baru sepertihalnya fiberglass.

Fiberglass adalah bahan paduan atau campuran beberapa bahan kimia (bahan komposit) yang bereaksi dan mengeras dalam waktu tertentu. Bahan ini mempunyai beberapa keuntungan dibandingkan bahan logam, diantaranya: ringan, mudah dibentuk, dan murah. Untuk membeli bahan bahan fiberglass (Mat, Resin, Catalyst, Pigment, WR, dan lain-lain) dapat dibeli di toko-toko bangunan. Untuk pembelian dalam jumlah yang besar dapat membelinya langsung kepada produsen, importir maupun ke agen penjualan. Namun kelemahan penggunaan bahan fiberglass adalah kekuatannya yang rendah, perlu perlatan keselamatan karena dapat mengganggu kesehatan, bahan kadang-kadang sulit didapat karena harus disuplai dari luar Kabupaten Bengkalis Seperti, Batam, Tanjung Pinang, Medan maupun luar negeri seperti Malaysia.

Penerapan fiberglass untuk kapal-kapal kecil, ini berarti dapat mengurangi penebangan kayu yang biasanya dibutuhkan untuk pemenuhan produksi kapal dengan bahan utama kayu. Di Indonesia, umumnya kapal-kapal kecil ataupun nelayan biasanya menggunakan kapal kayu, hal ini tentunya berdampak pada perusakan lingkungan, yang bertentangan dengan pelestarian lingkungan. Oleh karena itu dengan memberikan solusi baru pada pembuatan bahan fiberglass nantinya trend penggunaan kapal kayu bisa dialihkan ke fiber yang ramah lingkungan dan aman bagi pengguna.

Sehingga perlu kajian dan penelitian pemanfaatan teknologi pembuatan kapal fiberglass berbahan komposit serat alami yang murah dan 
efisien untuk bangunan kapal pada galangan tradisional di Kabupaten Bengkalis.

\subsection{Perumusan Masalah}

Dengan sulitnya dalam mendatangkan bahan baku utama fiberglass, seperti serat MAT dan WR (Woven Roofing) disamping mahalnya bahan serat terebut, maka perlu dilakukan penggunaan serat alami dan bahan lain yang digunakan sebagai pengganti serat sintetis pada bahan fiberglass. Penelitian ini dianggap perlu melakukan :

a. Analisis dan penentuan kriteria dan pembobotan penentuan bahan alternatif sebagai pengganti serat glass pada bahan fiberglass sebagai bahan utama pembuatan kapal.

b. Aplikasi dengan melakukan pembutan model kapal dari bahan fiberglass dengan menggunakan campuran penguatan serat sabut kelapa dan bahan kain/pakaian bekas

c. Membuat Spesimen pengujian untuk pengujian tarik dan uji bending, guna mengetahui kekuatan tarik dan tekan pada serat altermnatif fiber pada spesimen tersebut.

\subsection{Tujuan}

Dengan melakukan pengujian Mekanis serat Sabut kelapa dan Kain Bekas maka diperoleh kekuatan tarik yang optimal dan memenuhi standar BKI dan standar ASTM D-790 dan ASTM D-638. Penggunaan Serat bahan penguatan fiberglass alternatif ini diharapkan dapat menghemat biaya pengeluaran dalam pembuatan fiberglass disamping untuk mengurangi produk limbah lingkungan yang tidak terurai dalam tindakan menjaga kesehatan (menghindari zat racun) terhadap fiber sintetis, selain dapat digunakan sebagai bahan pembuatan kapal, juga dapat digunakan pada produk ataupun keperluan lain seperti : keramba, palka ikan, pelampung jaring serta peralatan rumah tangga lainnya.

\subsection{Manfaat Penelitian}

Manfaat penggunaan fiber komposit, diantaranya adalah memberikan konstribusi untuk mengurangi biaya produksi bahan fiberglass, memanfaatkan limbah pertanian olahan kelapa dan limbah masyarakat (pakaian bekas), mengurangi pencemaran lingkungan dari efek pemakaian serat fiberglass, memberikan konstribusi peluang kerja bagi petani kelapa, memberikan konstribusi dan solusi dalam pembuatan fiberglass yang ramah lingkungan serta memberikan kekuatan alternatif yang optimal.

\section{LANDASAN TEORI \\ 2.1 THE ANALYTIC HIERARCHY PROCESS (AHP)}

Analisis Hierarchy proses (AHP) adalah suatu teori umum tentang pengukuran yang digunakan untuk menemukan sekala rasio, baik dari perbandingan pasangan yang diskret maupun kontinyu. Perbandingan-perbandingan ini diambil dari ukuran aktual atau dari suatu skala dasar yang mencerminkan kekuatan perasaan dan preferensi relatif. AHP memiliki perhatian khusus tentang penyimpangan dari konsistensi, pengukuran, dan pada ketergantungan didalam dan diantara kelompok elemen strukturnya. AHP banyak ditemukan pada pengambilan keputusan untuk banyak kriteria, perencanaan (prediksi), alokasi sumber daya, penyusunan matriks input koefisien, penentuan prioritas dan strategi-strategi yang dimiliki pemain dalam situasi konflik dan lain sebagainya.

Tahap terpenting dalam proses Analytic Hierarchy Process adalah penilaian perbandingan pasangan, yang pada dasarnya merupakan perbandingan tingkat kepentingan antar komponen (elemen) dalam suatu tingkat hirarkhi. Penilaian dilakukan dengan cara membandingkan sejumlah kombinasi elemen yang ada pada tiap hirarkhi. Sehingga dapat dilakukan penilaian kuantitatif untuk mengetahui besarnya bobot setiap elemen. Untuk pembandingan pasangan, bentuk matriks merupakan bentuk yang lebih disukai. Beberapa keuntungan dengan menggunakan bentuk matriks adalah :

1. Bentuknya lebih sederhana

2. Merupakan alat yang cukup baik yang menawarkan kerangka untuk pengujian konsistensi.

3. Dapat diperoleh tambahan informasi melalui pembuatan seluruh pembandingan yang mungkin.

4. Dalam analisa sensitivitas dari seluruh tingkat hirarchy untuk mengubah kedalam judgement.

L. Saaty telah menyusun tabel skala perbandingan pasangan seperti yang dapat dilihat pada 
Tabel 1. Skala Perbandingan Pasangan

\begin{tabular}{|c|c|c|}
\hline $\begin{array}{l}\text { Nilai Intensitas } \\
\text { Kepentingan }\end{array}$ & Definisi Variabel & Penjelasan \\
\hline 1 & Sama pentingnya & $\begin{array}{l}\text { Kedua Variabel mempunyai } \\
\text { pengaruh yang sama pentingnya }\end{array}$ \\
\hline 3 & Sedikit 1ebih penting & $\begin{array}{l}\text { Sedikit lebih memihak pada satu } \\
\text { variabel dibandingkan dengan } \\
\text { pariabel lainnya. }\end{array}$ \\
\hline 5 & Lebih penting & $\begin{array}{l}\text { Lebih memihak pada satu } \\
\text { variabel dibandingkan } \\
\text { pasangannya. }\end{array}$ \\
\hline 7 & Sangat penting & $\begin{array}{l}\text { Sangat memihak pada satu } \\
\text { variabel dibandingkan } \\
\text { pasangannya. }\end{array}$ \\
\hline 9 & Mutlak lebih penting. & $\begin{array}{l}\text { Suatu variabel terbukti mutlak } \\
\text { lebih disukai di banding variabel } \\
\text { lain pada tingkat keyakinan } \\
\text { tertinggi. }\end{array}$ \\
\hline $2,4,6,8$ & Nilai antara & $\begin{array}{l}\text { Nilai ini diberikan bila terdapat } \\
\text { keraguan penilaian diantara dua } \\
\text { variabel penilaian berdekatan. }\end{array}$ \\
\hline
\end{tabular}

\subsection{Klasifikasi komposit}

Secara umum klasifikasi komposit sering digunakan antara lain seperti :

1. Klasifikasi menurut kombinasi material utama, seperti metal-organic atau metal anorganic.

2. Klasifikasi menurut karakteristik bulkform,sepertisistem matrikatau laminate.

3. Klasifikasi menurut distribusi unsur pokok, seperti continous dan discontinous.

4. Klasifikasi menurut fungsinya, seperti elektrikal atau structural.

Secara garis besar komposit diklasifikasikan menjadi tiga macam, yaitu:

1. Komposit serat (Fibrous Composites)

2. Komposit partikel (Particulate Composites)

3. Komposit lapis (Laminates Composites)

\subsection{Sabut Kelapa}

Salah satu Kabupaten yang relatif besar menghasilkan buah kelapa adalah Kabupaten Bengkalis di Propinsi Riau. Data pada tahun 2010 menunjukkan luas real lahan tanaman kelapa di Kabupaten Bengkalis adalah 16,982 hektar, dengan jumlah produksi sebesar 36.542 ton. Hasil sampingan pohon kelapa berupa tempurung, sabut, batang pohon, serta daun juga dapat diolah menjadi produk-produk yang mempunyai nilai jual.

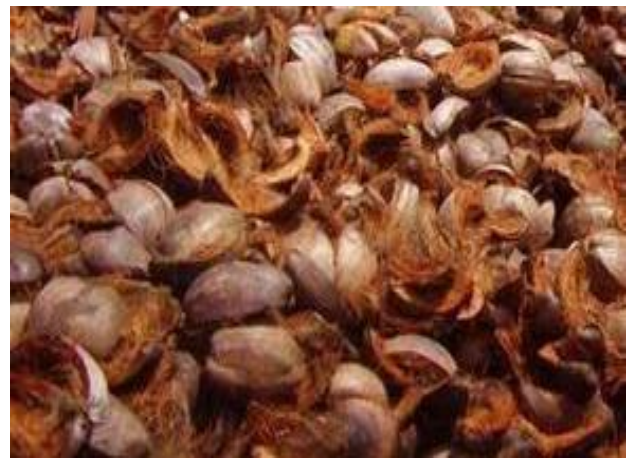

Gambar 1. Serat Sabut Kelapa

\subsection{Kain Bekas}

Bahan baku baju merupakan sisa limbah pemakaian manusia yang sudah tidak bisa digunakan lagi, pemanfaatan kain bekas perlu dilakukan berbagai macam bentuk dan produksi hasil olahan kain bekas, komposisi sampah dari limbah kain bekas yang dibuang tidak seberapa dibanding sampah rumah tangga. Namun jumlah tersebut akan terus bertambah, disebabkan sifatsifat yang dimiliki kain bekas, antara lain lama membusuk, lama terurai secara alami, akhirnya menjadi masalah bagi lingkungan.

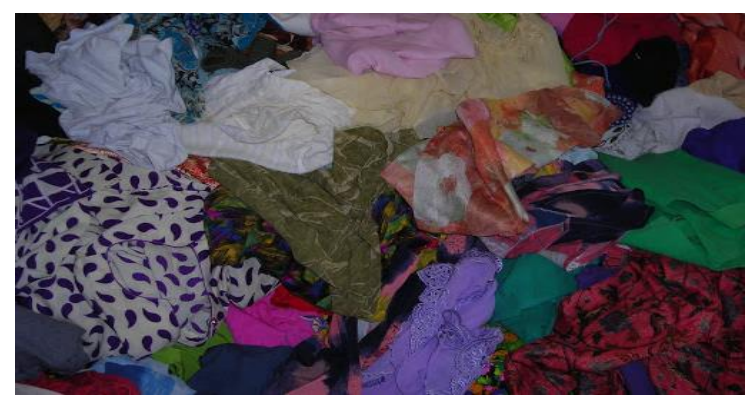

Gambar 2 Kain Bekas

\subsection{Keuntungan Pemakaian Material Fiber Alami (Biokomposit)}

Penggunaan material serat alami atau biokomposit yang bersifat organik memiliki berbagai keutungan. Hal inilah yang mendorong semakin optimisnya penggunaan fiber berpenguat serat alami (biokomposit), diantaranya adalah:

1. Bobot ringan

2. Mempunyai kekuatan dan kekakuan yang baik

3. Biaya produksi murah

4. Merupakan bahan organik yang dapat terurai

5. Tahan korosi

6. Tersedia oleh alam secara berlimpah

\subsection{Aplikasi di Bidang Marine}

Aplikasi penggunaan fiberglass di bidang marine sudah diperkenalkan secara komersial sejak tahun 1940-an. Pada bidang marine, fiber sering digunakan untuk pembuatan bodi kapal, pipa untuk fluida yang tidak berbahaya, peti kemas, peti es, tempat penyimpanan dan sebagainya. Pengunaan fiber dalam masalah ini tentunya beralasan, diantaranya adalah pemakaian fiber yang lebih ringan, kuat, mudah berolah gerak (manuverabilty), percepatan, dan tentunya lebih efisien. Khususnya untuk kapal-kapal kecil (boat) sangat penting untuk menggunakan penerapan fiber (P.K Mallick, Fiber Reinforced Composites, second edition, hal.11). 


\subsection{Dimensi Spacemen Benda Uji}

a. Geometri Spesimen Uji Bending ASTM D790

Geometri spesimen uji bending D-790

"Standard Test Methods for Flexural Properties of Unreinforced and Reinforced Plastics and Electrical Insulating Materials"

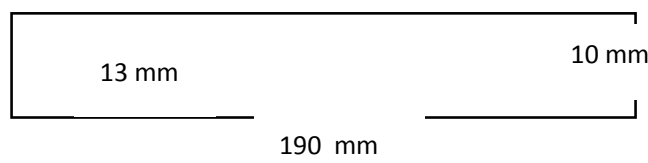

Gambar 3. Geometri Spesimen Bending (mm)

Harga momen maksimum sampel uji yang dikenai pengujian dengan three point bending dapat dirumuskan sebagai berikut :

$$
\mathrm{M} \quad=\frac{1}{2} \mathrm{P} \times \frac{1}{2} \mathrm{~L}=\frac{\mathrm{PL}}{4}
$$

Dimana:

$$
\mathrm{M}=\text { Momen maksimum (Nmm) }
$$

$\mathrm{P}=\operatorname{Beban}(\mathrm{N})$

$\mathrm{L}=$ Panjang span $(\mathrm{mm})$

Untuk dapat mengetahui nilai uji bending, terlebih dahulu harus mencari nilai momen, momen inersia, menghitung jarak momen ke beban.

$$
M=\frac{P . L}{4}
$$

Keterangan:

$\mathrm{M}=$ Momen $(\mathrm{Nmm})$

$\mathrm{P}=$ Beban tekan $(\mathrm{N})$

$\mathrm{L}=\mathrm{Jarak}$ tumpu $(\mathrm{mm})$

$$
\mathrm{C}=1 / 2 \mathrm{~h}
$$

Keterangan:

$\mathrm{h}=$ Tebal spesimen $(\mathrm{mm})$

$$
I=\frac{b \cdot h^{3}}{12}
$$

Keterangan:

$\mathrm{I}=$ Momen inersia $\left(\mathrm{mm}^{4}\right)$

$\mathrm{b}=$ Lebar spesimen $(\mathrm{mm})$

$\mathrm{h}=$ Tebal spesimen $(\mathrm{mm})$

$$
\sigma=\frac{M . C}{I}
$$

Keterangan :

$\sigma \quad=$ Tegangan normal $\left(\mathrm{N} / \mathrm{mm}^{2}\right)$

$\mathrm{M}=$ Momen maksimum pada spesimen (Nmm)

$\mathrm{C}=$ Jarak sumbu netral ke beban yang diberikan pada spesimen $(\mathrm{mm})$

I = Momen inersia penampang $\left(\mathrm{mm}^{4}\right)$

\section{b. Geometri Spesimen Uji Impact ASTM D 638} Type III.

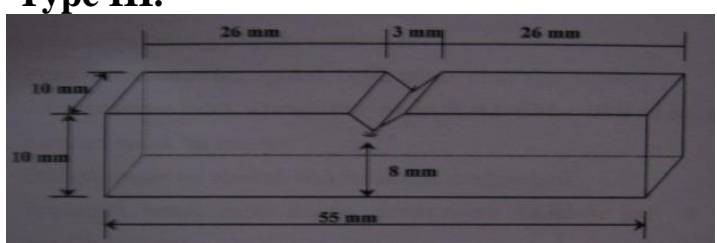

Gambar 4. Geometri Spesimen impak (dalam mm)

Untuk menghitung nilai uji impak, diperluan beberapa persamaan yaitu:

$$
\boldsymbol{H}=\boldsymbol{L}+\boldsymbol{x}
$$

Keterangan :

$\mathrm{L}=$ Jarak ujung sampel ke takikan

$\mathrm{X}=\mathrm{L} \mathrm{x} \sin \theta$

$\boldsymbol{h}=\boldsymbol{L}-\boldsymbol{y}$

Keterangan :

$\mathrm{L}=$ Jarak ujung sampel ke takikan

$\mathrm{y} \quad=\mathrm{L} \times \cos \beta$

$E=\boldsymbol{m} x \boldsymbol{g} x(H-l)$

Keterangan :

$\mathrm{m}=$ Berat Pendulum

$\mathrm{g}=$ Gravitasi

$$
A=l x h
$$

Keterangan :

l = Lebar Sampel

$\mathrm{h}=$ Tebal Sampel

$$
H I=\frac{E}{A}
$$

Keterangan :

$\mathrm{E}=$ Besarnya Usaha Mematahkan Sampel (kg.m)

$\mathrm{A}=$ Luas Penampang

\section{c. Validasi Hasil Pengujian Terhadap Kekuatan Ijin Menurut Aturan BKI.}

Pada Rules And Regulasion For The Clasification And Construction Of Ship, Biro Klasifikasi Indonesia (BKI) 1996, section 1.C.4.1.disyaratkan khusus dispesifikasikan untuk kapal-kapal FRP Dengan bahan penguat fiberglass yang diisi oleh serat penguat baik itu jenis mat dan Roving harus memiliki standart kekuatan sebagai berikut:

Tabel 2. Standart Kekuatan BKI Untuk material Fibre glass

\begin{tabular}{|c|l|c|l|}
\hline $\begin{array}{l}\text { Kuat Tarik } \\
(\mathrm{kg} / \mathrm{mm})\end{array}$ & $\begin{array}{l}\text { Modolus } \\
\text { Elastisitas } \\
\text { Kuat Tarik } \\
(\mathrm{kg} / \mathrm{mm} 2)\end{array}$ & $\begin{array}{l}\text { Kuat Lentur } \\
(\mathrm{kg} / \mathrm{mm} 2)\end{array}$ & $\begin{array}{l}\text { Modolus } \\
\text { Elastisitas } \\
\text { Kuat } \\
\text { Lentur } \\
(\mathrm{kg} / \mathrm{mm} 2)\end{array}$ \\
\hline $\mathbf{1 0}$ & $\mathbf{7 0 0}$ & $\mathbf{1 5}$ & $\mathbf{7 0 0}$ \\
\hline
\end{tabular}




\section{METODOLOGI PENELITIAN}

4.1 Penentuan Kriteria Dan Responden Komposit Alternatif Fiberglass

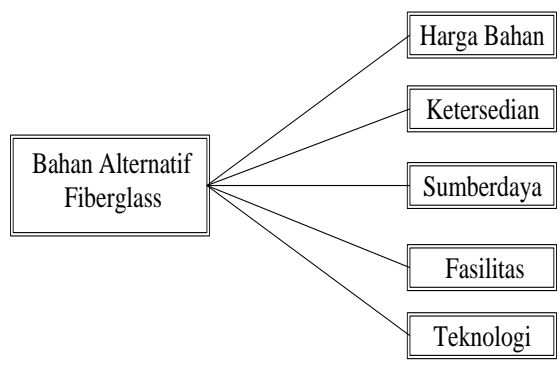

Gambar 5. Kriteria Bahan Komposit Alternatif Fiberglass

\section{- Harga Bahan}

Kriteria Harga Bahan adalah kemampuan bagi pihak galangan ataupun pemilik kapal dalam memperoleh bahan alternatif yang terkait pada harga pasar yang tentunya lebih murah dan mudah diperoleh dibandingkan dengan serat seintetis pencampur bahan fiberglass dalam melakukan pembuatan maupun perbaikan kapal.

\section{- Ketersediaan Bahan}

Ketersediaan Bahan dimaksud adalah tingkat kesulitan dalam perolehan bahan komposit alternatif yang seharusnya banyak tersedia sehingga dapat diperoleh dengan mudah oleh pihak galangan ataupun pemilik kapal di Kabupaten Bengkalis.

\section{- Sumberdaya}

Teknologi pencampuran dan penggunaan bahan komposit alternatif lebih mudah diterapkan dan diimplementasikan pada pembuatan atau pun perbaikan kapal.

\section{- Fasilitas}

Dalam Pengguanaan Bahan Komposit Alternatif hendaknya tanpa memerlukan peralatan dan fasilitas khusus dan rumit dibandingkan dengan penggunaan bahan serat sintetis yang biasa digunakan.

- Teknologi

Penerapan Teknologi Pencampuran bahan alternatif hendaknya dapat diimplementasikan dengan teknologi yang lebih sederhana dan tanpa memerlukan peralatan (tool) khusus yang mahal dan sulit diperoleh serta tanpa harus dengan keahlian khusus dan penerapanya.

\subsection{Responden Pembobotan Kriteria}

Survey dan Perolehan data berupa pembobotan kriteria oleh responden dilaksanakan di 4 (empat) desa yaitu Desa Meskom, Desa Kelapapati, Desa Selatbaru dan Desa Teluk
Pambang. Responden dibagi antas 4 kelompok yaitu :

1. Galangan kapal kayu

Oknum atau perorangan pemilik ataupun yang bekerja pada galangan kapal kayu, yang betulbetul mengerti tentang proses dan konstruksi dalam pembuatan kapal kayu ataupun fiberglass.

2. Galangan kapal fiber.

Oknum atau perorangan pemilik galangn ataupun yang bekerja pada galangan fiberglass, yang betul-betul mengerti/mahir tentang proses dan pencampuran bahan fiberglass ataupun konstruksi pembuatan kapal fiberglass.

3. Pemilik Kapal kayu

Perorangan yang bertindak sebagai pemilik kapal yang tentunya mengetahui karakteristik, harga dan ketersediaan bahan kayu yang digunakan pada konstruki kapal di Kabupaten Bengkalis.

Perorangan yang bertindak sebagai pemilik kapal dari bahan fiberglass yang tentunya mengetahui karakteristik, harga dan ketersediaan bahan dan konstruki kapal fiberglass di Kabupaten Bengkalis.

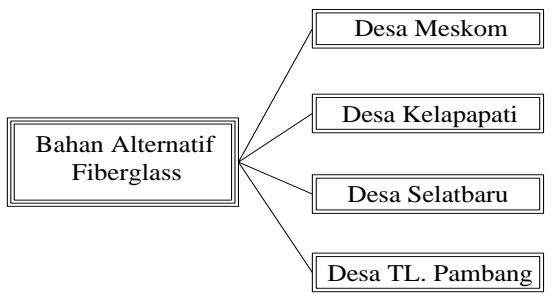

Gambar 6. Lokasi Perolehan data dan Responden

Tabel 3.Lokasi dan kelompok responden survey

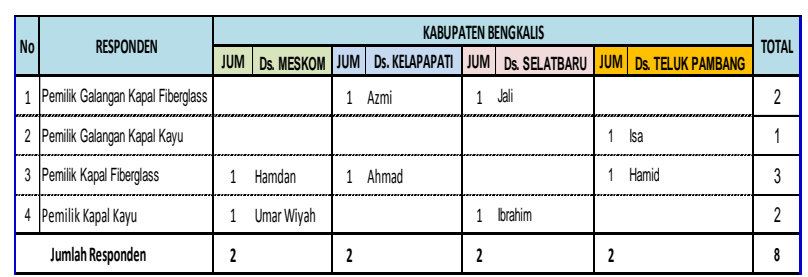




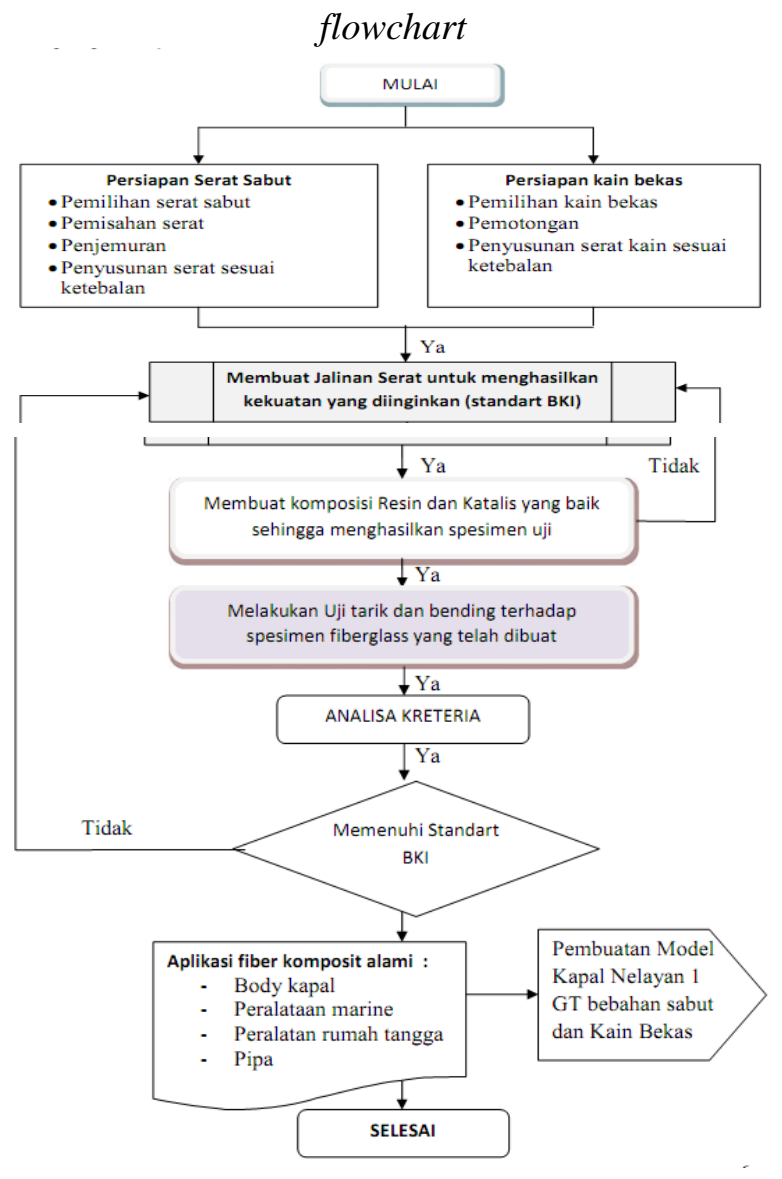

4. ANALISA DATA DAN PEMBAHASAN 4.1 Kriteria Bahan Komposit Alternatif

Bahan alternatif komposit serat glass pada campuran fiberglass yang biasanya menggunakan serat MAT dan WR (Wooven Roofing) pada aplikasi pembuatan kapal fiberglass, dilakukan pemilihan bahan dengan ketentuan lima kriteria tersebut diatas yang kemudian dilakukan survey dengan pembobotan perbandingan kriteria yang terpenting diantara pasangan oleh kelompok responden di lima desa di Kabupaten Bengkalis. Dengan hasil pembobotan oleh responden seperti yang ditunjukkan pada tabel-tabel berikut :

1. Responden Pemilik Galangan Fiberglass (Azmi)

\begin{tabular}{|l|l|c|c|c|c|c|}
\hline \multicolumn{1}{|c|}{ KRITERIA } & & HB & KB & SM & FP & TP \\
\hline Harga Bahan (HB) & HB & 1 & 1 & 1 & 1 & 5 \\
\hline Ketersediaan Bahan (KB) & KB & 1 & 1 & 5 & 1 & 5 \\
\hline Sumberdaya Manusia (SM) & SM & 1 & $1 / 5$ & 1 & 5 & 1 \\
\hline Fasilitas (FP) & FP & 1 & 1 & $1 / 5$ & 1 & 3 \\
\hline Teknologi (TP) & TP & 1 & $1 / 5$ & 1 & $1 / 3$ & 1 \\
\hline
\end{tabular}

2. Responden Pemilik Galangan Kapal Fiberglass (Jali)

\begin{tabular}{|c|c|c|c|c|c|c|}
\hline \multicolumn{2}{|l|}{ KRITERIA } & $\mathrm{HB}$ & KB & SM & FP & TP \\
\hline Harga Bahan (HB) & HB & 1 & 7 & 1 & 1 & 5 \\
\hline Ketersediaan Bahan (KB) & KB & $1 / 7$ & 1 & 1 & 7 & 5 \\
\hline Sumberdaya Manusia (SM) & SM & 1 & 1 & 1 & 7 & 7 \\
\hline Fasilitas (FP) & FP & 1 & $1 / 7$ & $1 / 7$ & 1 & 7 \\
\hline Teknologi (TP) & TP & $1 / 5$ & $1 / 5$ & $1 / 7$ & $1 / 7$ & 1 \\
\hline
\end{tabular}

3. Responden Pemilik Galangan Kapal Kayu (Isa)

\begin{tabular}{|l|c|c|c|c|c|c|}
\hline \multicolumn{2}{|c|}{ KRITERIA } & HB & KB & SM & FP & TP \\
\hline Harga Bahan (HB) & HB & 1 & 7 & 7 & 7 & 7 \\
\hline Ketersediaan Bahan (KB) & KB & $1 / 7$ & 1 & 1 & 5 & 1 \\
\hline Sumberdaya Manusia (SM) & SM & $1 / 7$ & 1 & 1 & 7 & 7 \\
\hline Fasilitas (FP) & FP & $1 / 7$ & $1 / 5$ & $1 / 7$ & 1 & 5 \\
\hline Teknologi (TP) & TP & $1 / 7$ & 1 & $1 / 7$ & $1 / 5$ & 1 \\
\hline
\end{tabular}

4. Responden Pemilik Kapal Fiberglass (Hamdan)

\begin{tabular}{|l|c|c|c|c|c|c|}
\hline \multicolumn{2}{|c|}{ KRITERIA } & HB & KB & SM & FP & TP \\
\hline Harga Bahan (HB) & HB & 1 & 1 & 1 & 5 & 1 \\
\hline Ketersediaan Bahan (KB) & KB & 1 & 1 & 7 & 1 & 1 \\
\hline Sumberdaya Manusia (SM) & SM & 1 & $1 / 7$ & 1 & 1 & 1 \\
\hline Fasilitas (FP) & FP & $1 / 5$ & 1 & 1 & 1 & 1 \\
\hline Teknologi (TP) & TP & 1 & 1 & 1 & 1 & 1 \\
\hline
\end{tabular}

5. Responden Pemilik Kapal Fiberglass(Ahmad)

\begin{tabular}{|l|c|c|c|c|c|c|}
\hline \multicolumn{2}{|c|}{ KRITERIA } & HB & KB & SM & FP & TP \\
\hline Harga Bahan (HB) & HB & 1 & 7 & 7 & 1 & 1 \\
\hline Ketersediaan Bahan (KB) & K & $1 / 7$ & 1 & 1 & 1 & 1 \\
\hline Sumberdaya Manusia (SM) & TA & $1 / 7$ & 1 & 1 & 4 & 7 \\
\hline Fasilitas (FP) & Q & 1 & 1 & $1 / 4$ & 1 & 1 \\
\hline Teknologi (TP) & Vs & 1 & 1 & $1 / 7$ & 1 & 1 \\
\hline
\end{tabular}

6. Responden Pemilik Kapal Fiber (Hamid)

\begin{tabular}{|l|c|c|c|c|c|c|}
\hline \multicolumn{1}{|c|}{ KRITERIA } & HB & KB & SM & FP & TP \\
\hline Harga Bahan (HB) & HB & 1 & 1 & 1 & 1 & 1 \\
\hline Ketersediaan Bahan (KB) & K & 1 & 1 & 1 & 1 & 1 \\
\hline Sumberdaya Manusia (SM) & TA & 1 & 1 & 1 & 1 & 1 \\
\hline Fasilitas (FP) & Q & 1 & 1 & 1 & 1 & 5 \\
\hline Teknologi (TP) & Vs & 1 & 1 & 1 & $1 / 5$ & 1 \\
\hline
\end{tabular}

7. Responden Pemilik Kapal Kayu (Umar Wiyah)

\begin{tabular}{|l|c|c|c|c|c|c|}
\hline \multicolumn{2}{|c|}{ KRITERIA } & HB & KB & SM & FP & TP \\
\hline Harga Bahan (HB) & HB & 1 & 1 & 5 & 5 & 1 \\
\hline Ketersediaan Bahan (KB) & K & 1 & 1 & 1 & 1 & 5 \\
\hline Sumberdaya Manusia (SM) & TA & $1 / 5$ & 1 & 1 & 1 & 5 \\
\hline Fasilitas (FP) & Q & $1 / 5$ & 1 & 1 & 1 & 5 \\
\hline Teknologi (TP) & Vs & 1 & $1 / 5$ & $1 / 5$ & $1 / 5$ & 1 \\
\cline { 1 - 4 } & & &
\end{tabular}


8. Responden Pemilik Kapal Kayu (Ibrahim)

\begin{tabular}{|l|c|c|c|c|c|c|}
\hline \multicolumn{2}{|c|}{ KRITERIA } & HB & KB & SM & FP & TP \\
\hline Harga Bahan (HB) & HB & 1 & 1 & 1 & 5 & 5 \\
\hline Ketersediaan Bahan (KB) & K & 1 & 1 & 5 & 7 & 1 \\
\hline Sumberdaya Manusia (SM) & TA & 1 & $1 / 5$ & 1 & 5 & 1 \\
\hline Fasilitas (FP) & Q & $1 / 5$ & $1 / 7$ & $1 / 5$ & 1 & 1 \\
\hline Teknologi (TP) & Vs & $1 / 5$ & 1 & 1 & 1 & 1 \\
\hline
\end{tabular}

9. Bobot rata-rata kriteria oleh responden

\begin{tabular}{|l|c|c|c|c|c|c|}
\hline \multicolumn{2}{|c|}{ KRITERIA } & HB & KB & SM & FP & TP \\
\hline Harga Bahan (HB) & HB & 1,00 & 2,07 & 1,99 & 2,33 & 2,33 \\
\hline Ketersediaan Bahan (KB) & KB & 0,48 & 1,00 & 1,91 & 1,99 & 1,83 \\
\hline Sumberdaya Manusia (SM) & SM & 0,50 & 0,52 & 1,00 & 2,89 & 2,54 \\
\hline Fasilitas (FP) & FP & 0,43 & 0,50 & 0,35 & 1,00 & 2,68 \\
\hline Teknologi (TP) & TP & 0,52 & 0,55 & 0,39 & 0,37 & 1,00 \\
\hline \multicolumn{2}{|c|}{ JUMLAH } & $\mathbf{2 , 9 4}$ & 4,65 & $\mathbf{5 , 6 4}$ & $\mathbf{8 , 5 9}$ & $\mathbf{1 0 , 3 7}$ \\
\hline
\end{tabular}

10. Bobot Prioritas Umum kriteria

\begin{tabular}{|l|l|c|c|c|c|c|c|r|}
\hline \multicolumn{2}{|c|}{ KRITERIA } & \multicolumn{1}{c|}{ HB } & KB & SM & FP & TP & JUMLAH & PRIORITAS \\
\hline Harga Bahan (HB) & HB & 0,340 & 0,446 & 0,353 & 0,272 & 0,225 & 1,63596 & 0,3272 \\
\hline Ketersediaan Bahan (KB) & KB & 0,164 & 0,215 & 0,338 & 0,232 & 0,176 & 1,12549 & 0,2251 \\
\hline Sumberdaya Manusial(SM) & SM & 0,171 & 0,113 & 0,177 & 0,337 & 0,245 & 1,04274 & 0,2085 \\
\hline Fasilitas (FP) & IP & 0,146 & 0,108 & 0,061 & 0,116 & 0,258 & 0,68982 & 0,1380 \\
\hline Teknologi(TP) & TP & 0,178 & 0,118 & 0,070 & 0,044 & 0,096 & 0,50599 & 0,1012 \\
\hline
\end{tabular}

\begin{tabular}{|c|c|c|c|c|c|c|c|c|c|}
\hline \multirow{2}{*}{\multicolumn{2}{|c|}{ KRITERIA }} & HB & $\mathrm{KB}$ & SM & $\mathrm{FP}$ & TP & \multirow{3}{*}{$\begin{array}{r}\text { JUMLAH } \\
1,767 \\
\end{array}$} & \multirow{3}{*}{$\begin{array}{r}\text { PRIORITAS } \\
0,327\end{array}$} & \multirow{3}{*}{$\frac{\lambda}{5,40}$} \\
\hline & & \multirow{2}{*}{$\begin{array}{l}0,327 \\
0,327 \\
\end{array}$} & \multirow{2}{*}{$\begin{array}{l}0,23 \\
0,467 \\
, 4\end{array}$} & \multirow{2}{*}{\begin{tabular}{r|}
0,21 \\
0,415 \\
\end{tabular}} & \multirow{2}{*}{$\begin{array}{r}0,14 \\
0,322 \\
\end{array}$} & \multirow{2}{*}{$\begin{array}{r}0,10 \\
0,236 \\
\end{array}$} & & & \\
\hline Harga Bahan (AB) & HB & & & & & & & & \\
\hline Ketersediaan Bahan (KB) & $\mathrm{KB}$ & 0,158 & 0,225 & 0,398 & 0,274 & 0,185 & 1,240 & 0,225 & 5,51 \\
\hline Sumberdaya Manusia (SM) & SM & 0,164 & 0,118 & 0,209 & 0,399 & 0,57 & 1,147 & 0,209 & 5,50 \\
\hline Fasilitzs $[$ FP) & $\mathrm{FP}$ & 0,140 & 0,113 & 0,072 & 0,138 & 0,271 & 0,734 & 0,138 & 5,32 \\
\hline Teknologi (TP) & $\mathbb{T P}$ & 0,172 & 0,123 & 0,082 & 0,052 & 0,101 & 0,530 & 0,101 & 5,23 \\
\hline & & & & & & & & 1,000 & 26,96 \\
\hline
\end{tabular}

11. Urutan Prioritas Kriteria dan Indeks Konsistensi Rasio Kriteria

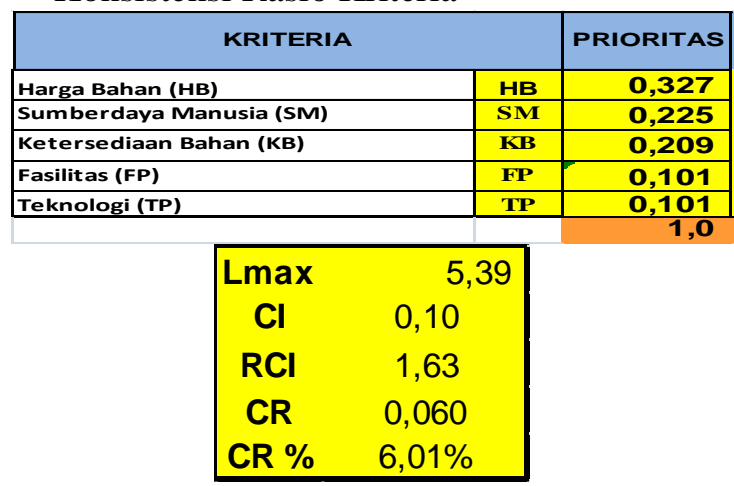

12. Urutan Prioritas

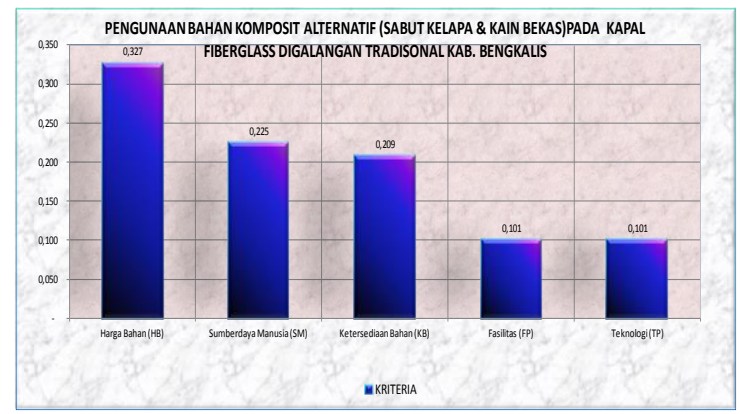

Gambar 7. Urutan Prioritas

\subsection{Proses Pembuatan Sampel}

Sampel yang dibuat berjumlah tiga jenis, yaitu sampel yang terbuat dari serat kelapa, dan kain bekas. kedua jenis ini akan dibuat masingmasing sebanyak 6 buah sampel untuk 6 kali pengujian bending dan 6 kali pengujian impak sehingga jumlah keseluran sampel adalah 18 sampel uji bending dan 18 sampel uji impak.

1. Proses Pembuatan Sampel dari Serabut Kelapa

a. Serabut Kelapa dikumpulkan, kemudian dipisahkan-pisahkan dari kulitnya. Serbaut direndam aquades selama 2 hari dan kemudian dijemur sampai serabut benar-benar kering.

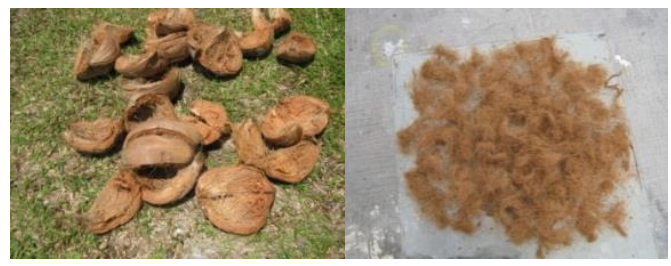

Gambar 6. Pengumpulan dan penjemuran Serabut

b. Selanjutnya mempersiapkan bahan dan peralatan untuk membuat sampel, yaitu resin, serabut kelapa, katalis, cetakan, wax, wadah dan kuas.

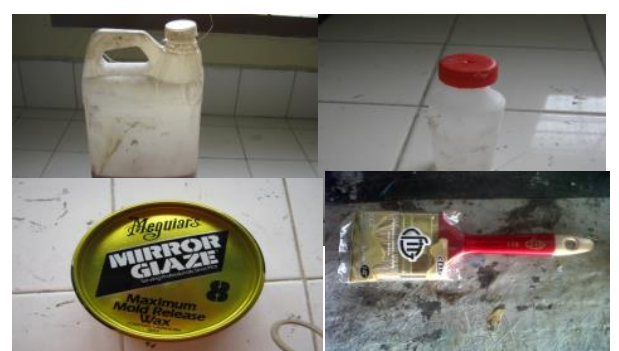

Gambar 7. Resin (A), Katalis (B), Wax (C), Kuas (D)

c. Mempersiapkan cetakan yang akan menjadi wadah untuk proses pencetakan sampel. Sebelumnya, cetakan diolesi wax agar sampel tidak lengket pada cetakan.

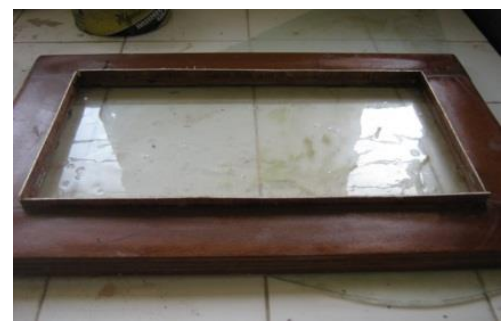

Gambar 8. Cetakan 
d. Proses laminasi dimulai dengan mengoleskan resin pada alas cetakan.

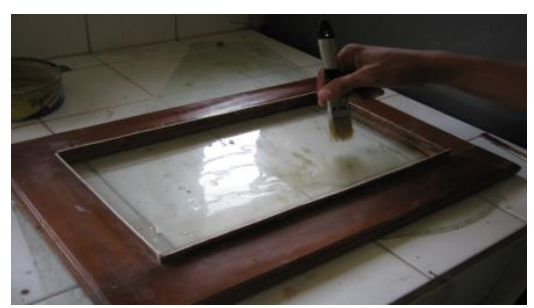

Gambar 9. Pengolesan Resin

e. Serabut yang telah dijemur sampai kering, digunting-gunting secara acak sehingga ukurannya menjadi kecil.

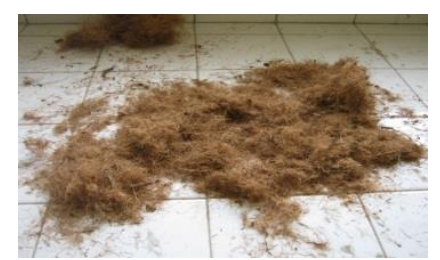

Gambar 10. Serabut yang telah digunting

f. Serabut tersebut di letakkan secara acak pada cetakan yang telah diolesi resin hingga ketebalan yang diinginkan. Kemudian diolesi resin hingga serabut-serabut tersebut basah dan tenggelam oleh resin.

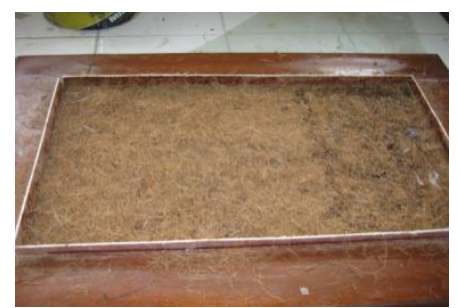

Gambar 11. Peletakan Serabut Secara Acak

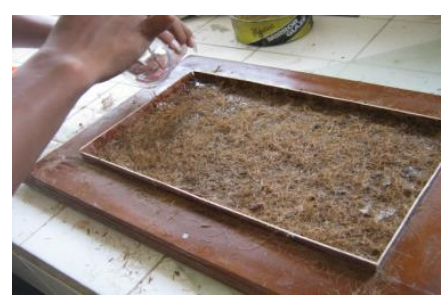

Gambar 12.. Pegolesan Resin

g. Setelah proses pencetakan selesai, sampel kemudian dijemur dan setelah kering dipotong sesuai dengan ukuran standar.

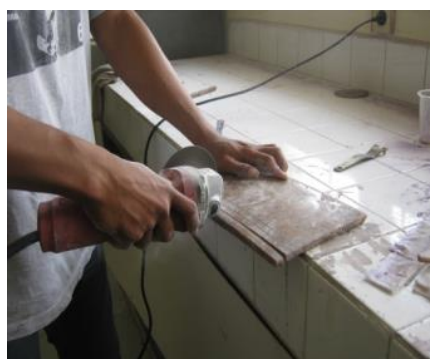

Gambar 13. Pemotongan sampel dengan gerinda

2. Proses pembuatan sampel kain bekas satun a. Mempersiapkan kain sebagai serat penguat.

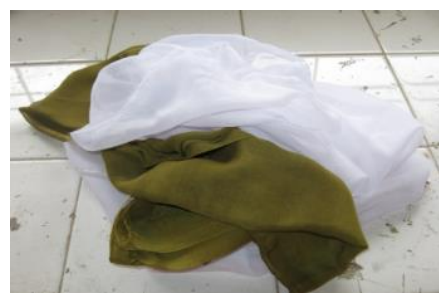

Gambar 14. Kain bekas sebagai pengganti serat

b. Proses pembuatan sampel dari kain satun tidak jauh berbeda dengan proses pembuatan sampel dari serabut kelapa.

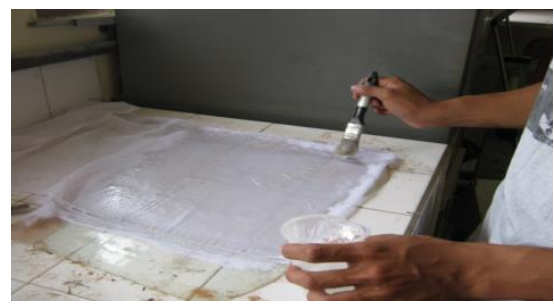

Gambar 15. Proses laminasi

c. Setelah proses laminasi selesai, sampel dijemur dan dipotong sesuai ukuran yang telah ditentukan.

3. Proses Pembuatan Sampel kain bekas kaos

a. Mempersiapkan singlet sebagai serat penguat.

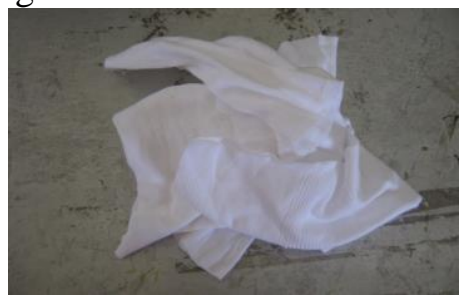

Gambar 16. Kain bekas kaos

b. Proses pembuatan sampel dari singlet tidak jauh berbeda dengan proses pembuatan sampel dari serabut kelapa. 


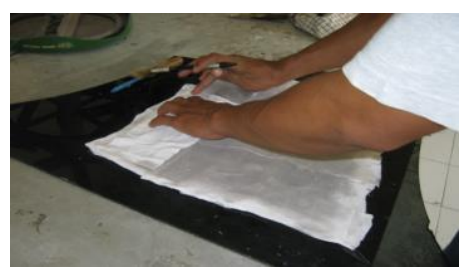

Gambar 17. Proses laminasi

c. Setelah proses laminasi selesai, sampel dijemur dan dipotong sesuai ukuran yang telah ditentukan.

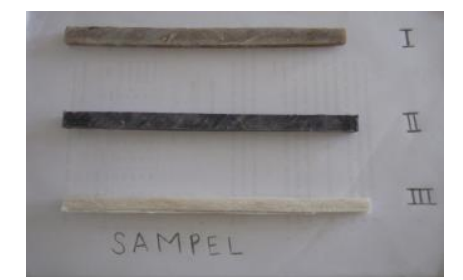

Gambar 18.Sampel uji bending

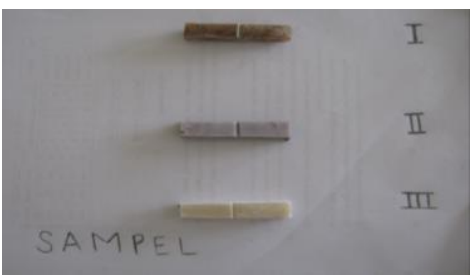

Gambar 19. Sampel uji impak

\subsubsection{Analisa Dan Hasil Data Pengujian \\ Bending}

Pengujian Bending dilakukan pada laboraturium Jurusan Teknik Mesin Polteknik Negeri Bengkalis pada tanggal 25 Oktober 2014 jam 14.00 WIB s/d selesai.

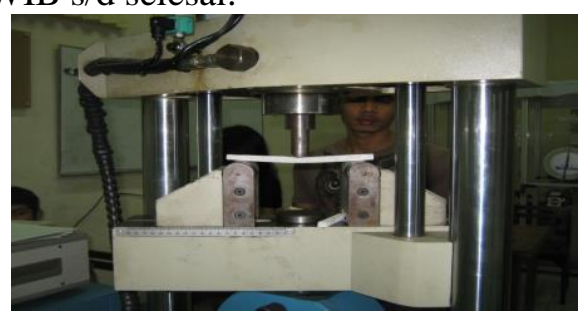

Gambar 20. Pengujian Bending yang dilakukan Tabel 4. Hasil Uji Bending

\begin{tabular}{|l|l|l|l|l|l|l|c|}
\hline Sampel & I & II & III & IV & V & VI & Rata-Rata \\
\hline Katun & 10.9 & 9.97 & 14.6 & 13.7 & 9.97 & 18.3 & 12.89 \\
\hline Serabut Kelapa & 1.53 & 1.62 & 3.48 & 3.67 & 3.29 & 2.55 & 2.69 \\
\hline Kaos & 6.27 & 7.19 & 6.27 & 5.34 & 6.27 & 8.12 & 6.58 \\
\hline
\end{tabular}

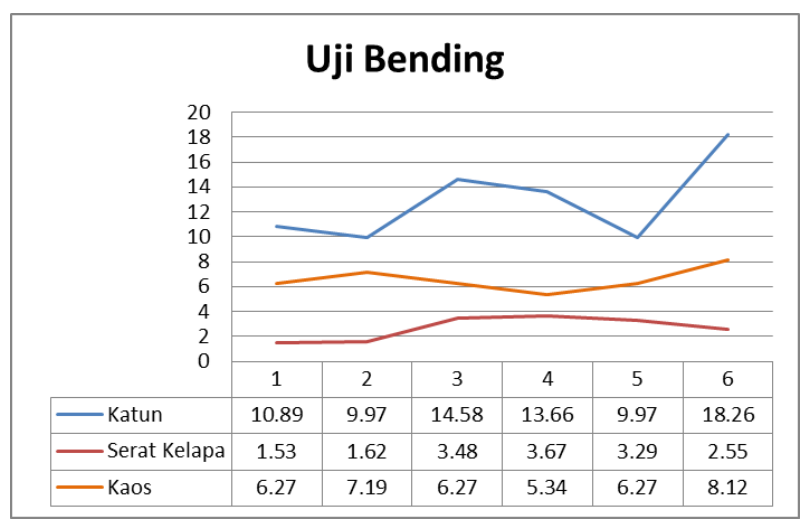

Gambar 21. Grafik Uji Bending

\section{Hasil Perhitungan BKI}

Nilai minimum yang disyaratkan BKI dalam rules BKI 2006 untuk kuat tekuk adalah:

Kekuatan tekuk:

$\mathrm{RB}=502 \$ 2+106.8[\mathrm{Mpa}]$

Keterangan :

$$
=\text { kandungan volume serat }
$$

Tabel 5.Nilai Minimum BKI

\begin{tabular}{|c|c|c|c|c|}
\hline No & Sampel & Uji Bending & $\Phi$ & BKI \\
\hline 1 & Jilbab & 12,88 & 0,18965986 & 124,8574 \\
\hline 2 & Serabut Kelapa & 2,69 & 22,2211538 & 247984,2 \\
\hline 3 & Singlet & 6,57 & 0,61955556 & 299,4922 \\
\hline
\end{tabular}

Berdasarkan Tabel 5 nilai rata-rata uji bending yang paling tinggi dihasilkan oleh sampel yang terbuat kain bekas sebagai pengganti serat penguat. Sementara nilai rata-rata terkuat yang kedua dihasilkan oleh sampel yang terbuat dari singlet sebagai pengganti serat penguat dan nilai rata-rata terendah dihasilkan oleh sampel serabut kelapa sebagai serat penguat.

Kemungkinan tingginya nilai rata-rata uji bending sampel jilbab ini dikarenakan bahan material pembentuk jilbab adalah poliester, dimana poliester ini adalah bahan pembentuk mat dan WR. Namun, untuk pembuatan jilbab digunakan juga bahan lain dan kandungan polisternya sedikit saja.

\subsubsection{Analisa dan hasil data Pengujian Impak (impact)}

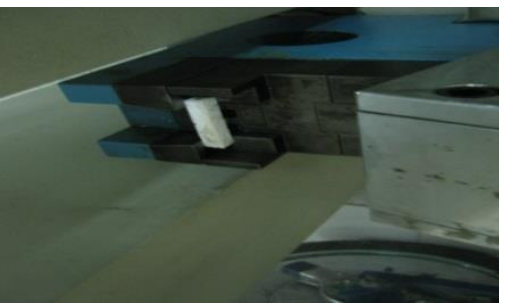

Gambar 21. Pengujian Impak 
Tabel 6. Hasil Uji Impak

\begin{tabular}{|l|r|r|r|r|r|r|r|}
\hline Sampel & \multicolumn{1}{c|}{ I } & \multicolumn{1}{c|}{ II } & \multicolumn{1}{c|}{ IV } & \multicolumn{1}{c|}{ V } & \multicolumn{1}{c|}{ VI } & Rata-Rata \\
\hline Katun & -0.40 & 1.92 & -0.69 & 1.92 & -1.31 & -1.92 & -0.08 \\
\hline Serat & -1.92 & 0.94 & 1.92 & -1.92 & 0.67 & -0.69 & -0.17 \\
\hline Kaos & 0.24 & -0.69 & -0.40 & 1.92 & -0.69 & -0.40 & 0.00 \\
\hline
\end{tabular}

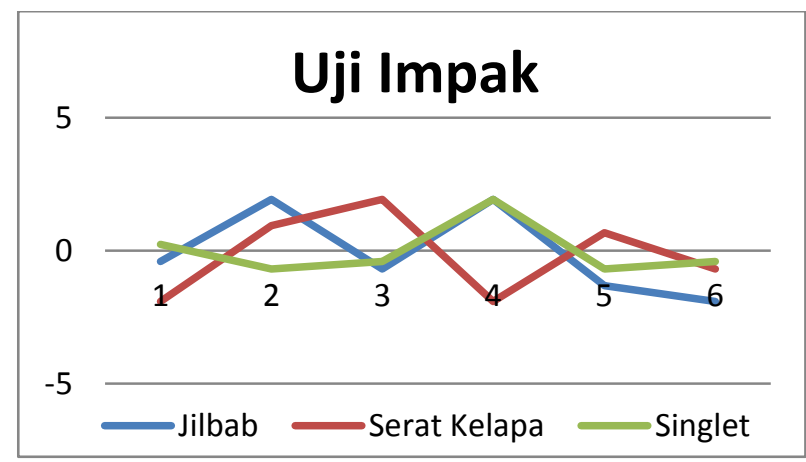

Gambar 22.. Grafik Nilai Uji Impak

\subsubsection{Pembuatan Model}

Pembuatan model kapal dilakukan dengan dua bahan alternatif meliputi serat sabut kelapa dan kain bekas. Untuk sabut voleme bahan yang dibutuhkan adalah resin $2,2 \mathrm{~kg}$, pigmen $1 \mathrm{gr}$, aeorosil 220 gr, dan katalis 110 gr, dengan berat sabut $10,3018 \mathrm{~cm}^{2}$, lambung $400 \mathrm{~cm}^{2}, 835,06 \mathrm{~cm}^{2}$ untuk bangunan atas, sedangkan untuk kain bekas banyak bahan yang dihabiskan yaitu resin $1,76 \mathrm{~kg}$, pigmen 1 gr, aeorosil 220 gr, dan katalis 110 gr, dengan ukuran kain $11,025 \mathrm{~cm}^{2}, 400 \mathrm{~cm}^{2}$ untuk lambung, dan $835,06 \mathrm{~cm}^{2}$ untuk bangunan atas kapal.

\subsubsection{Pembuatan Cetakan}

Pembuatan cetakan model mengunakan bahan fiberglass dimana bentuk dan ukuran disesuaikan dengan kapal nelayan 1 GT yang ada di Kabupaten Bengkalis.

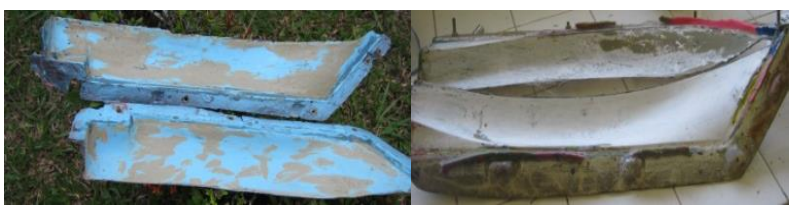

\subsubsection{Pembuatan Model Sabut Kelapa}

A. Persiapan Bahan komposit

- Pemisahan serat dari sabut kelapa

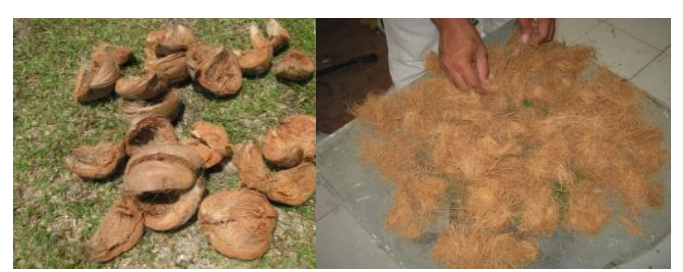

- Penjemuran

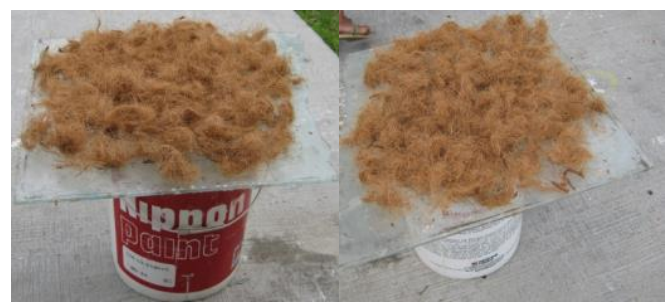

\section{B. Pembuatan Lambung}

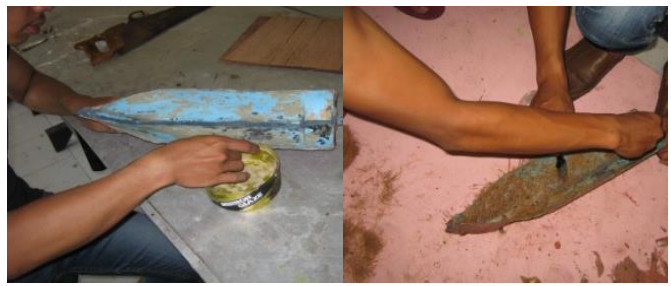

\section{Pembuatan Bangunan atas}

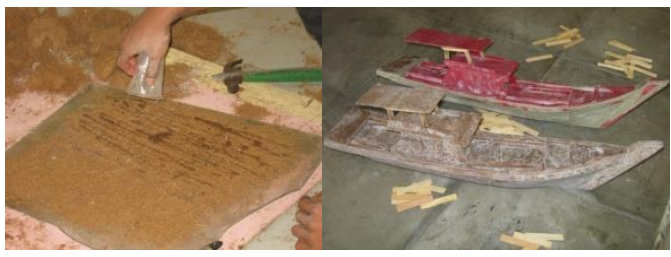

\section{Finishing}

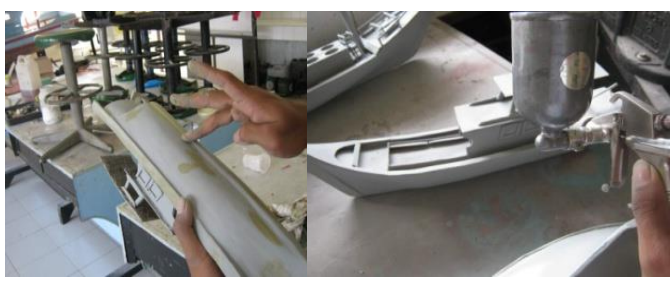

\subsubsection{Pembuatan Model Kain Bekas}

A. Persiapan Bahan komposit

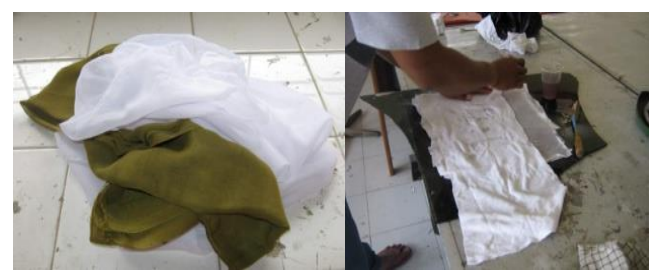

\section{B. Pembuatan Lambung}

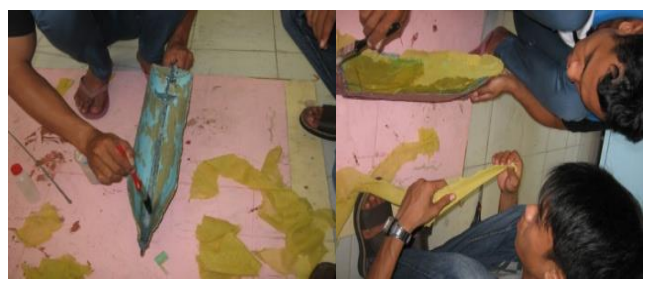




\section{Pembuatan Bangunan atas}

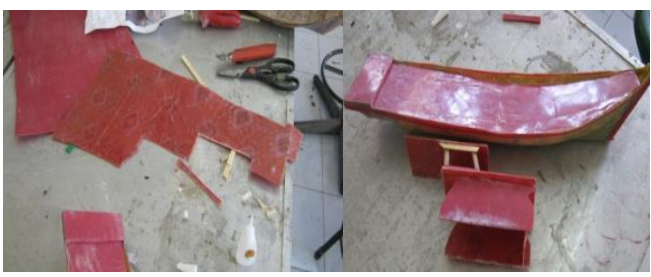

D. Finishing
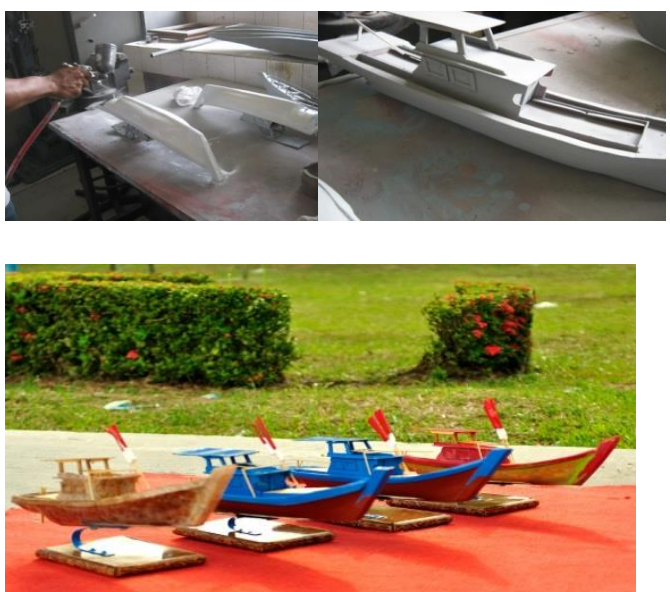

Tahapan pembuatan model kapal sedikit memiliki kesamaan dengan pembuatan kapal sebenarnya. Dimana diawali dengan pembuatan cetakan dan kemudian dilakukan pembuatan lambung kapal. Hanya saja dalam pembuatan kapal nyata diikuti dengan pembuatan gading dang penguatan lambung lainnya untuk tahapan selanjutnya yang mengacu pada hasil perancangan.

\section{KESIMPULAN DAN SARAN \\ 5.1 KESIMPULAN}

Kesimpulan yang diperoleh setelah melakukan penelitian ini adalah :

1. Serat komposit (sabut kelapa dan kain bekas) adalah salah satu komposit alternatif yang berpotensi untuk dikembangkan pada Kabupaten Bengkalis dan sekitarnya sebagai pengganti serat sintetis penguat fiber.

2. Urutan prioritas kriteria Bahan alternatif pengganti serat sintetis fiberglass dengan metode AHP, maka harga bahan memiliki nilai paling besar, dikuti oleh sumberdaya manusia, ketersediaan, Fasilitas dan teknologi karena dalam proses pembuatan kapal harga bahan menjadi sangat penting, karena harga bahan serat fiber yang relatif mahal.

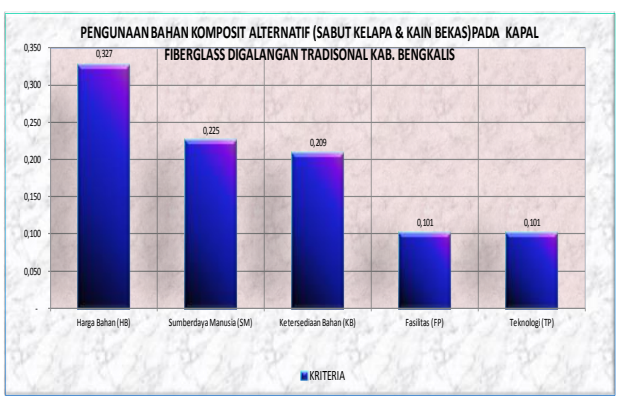

Dengan validasi analisis $<10 \%$ yang artinya dimana kebenaran data dapat dipertanggung jawabkan.

3. Dari pengujian yang telah dilakukan didapatkan hasil kekuatan bending dan Impak serat komposit alternative, dengan kekuatan sebagai berikut:

\begin{tabular}{|c|c|c|}
\hline Sampel & Kekuatan Bending & Kekuatan Impak \\
\hline Jilbab & $12,88 \mathrm{Mpa}$ & $-0,0808$ \\
\hline Serat & $2,69 \mathrm{Mpa}$ & $-0,16533$ \\
\hline Singlet & $6,57 \mathrm{Mpa}$ & $-0,00427$ \\
\hline
\end{tabular}

4. Nilai uji impak yang dihasilkan adalah minus. Hal ini kemungkinan terjadi karena pembebanan yang diberikan pada saat pengujian spesimen terlalu besar terhadap variasi specimen pengujian. Meskipun demikian, terdapat beberapa spesimen dengan nilai uji yang optimal. Seperti specimen kain bekas katun yang dua dari enam sampel yang diuji memiliki hasil yang positif dan cukup optimal. Ini membuktikan bahwa sampel yang diuji memenuhi ketentuan dan prosedural pengujian.

\section{DAFTAR PUSTAKA}

[1] Bramantyo, A. 2008. Pengaruh Konsentrasi Serat Rami. Skripsi. Fakultas Teknik Universitas Indonesia. Jakarta.

[2] Biro Klasifikasi Indonesia,1996."Rules and Regulation for The Classification and Construction of Ships", Jakarta.

[3] Engarwati. Pristiwi T, 2011 "Pemanfaatan Limbah (Sekam Padi Dan Sabut Kelapa) Sebagai Isian Batako (Bata Beton) Ramah Lingkungan” Skripsi S1 Teknik Sipil Universitas Pembangunan Nasional (UPN) Veteran Jawatimur, Surabaya.

[4] Fernata, Feri 2012. Kapal Fibreglas Sebagai Altenatif Pengganti Kapal Kayu 3 Gross Tonnage, Penelitian Prioritas Nasional Masterplan Percepatan dan Perluasan Pembangunan Ekonomi Indonesia (PENPRINAS MP3EI 2012). 
[5] Irawan. Y, 2008, “Pengembangan Serat Sabut Kelapa untuk Pembuatan Papan dengan berrbagai jenis matrik : Semen, Gypsum, dan Tanah Liat", Institut Teknologi Nasional, Jakarta.

[6] Mujiyanto, 2009 "Pemanfaatan Kain Perca sebagai Campuran Beton”, Thesis Fakultas Teknik Universitas Gajah Mada, Yogyakarta.

[7] Nurul Anwar Mohammad., 2007 “Analisis Sifat Mekanis Polyester dengan Penambahan Serat Gelas”, Jurusan Teknik Mesinfakultas Teknik Universitas Muhammadiyah Malang.

[8] Razali., 2006. Buku Ajar Kapal Non Baja. Jurusan Teknik Perkapalan Politeknik Bengkalis.

[9] Riau Terkini, 2006. Pemberantasan Illegal Logging Ancam Kelangsungan Industri Kapal Tradisional Rabu, 07. September 2013.

[10] Watson, D. G. M , 1998. Practical Ship Design, Elseveir, Amsterdam. 